RECEIVED BY TIC MAR 291973

\title{
RADIOISOTOPE PROGRAM (8000) PROGRESS REPORT FOR FEBRUARY 1973
}

A. F. Rupp

\section{OAK RIDGE NATIONAL LABORATORY}




\section{DISCLAIMER}

This report was prepared as an account of work sponsored by an agency of the United States Government. Neither the United States Government nor any agency Thereof, nor any of their employees, makes any warranty, express or implied, or assumes any legal liability or responsibility for the accuracy, completeness, or usefulness of any information, apparatus, product, or process disclosed, or represents that its use would not infringe privately owned rights. Reference herein to any specific commercial product, process, or service by trade name, trademark, manufacturer, or otherwise does not necessarily constitute or imply its endorsement, recommendation, or favoring by the United States Government or any agency thereof. The views and opinions of authors expressed herein do not necessarily state or reflect those of the United States Government or any agency thereof. 


\section{DISCLAIMER}

Portions of this document may be illegible in electronic image products. Images are produced from the best available original document. 
This report was prepared as an account of work sponsored by the United States Government. Neither the United States nor the United States Atomic Energy Commission, nor any of their employees, nor any of their contractors, subcontractors, or their employees, makes any warranty, express or implied, or assumes any legal liability or responsibility for the accuracy, completeness or usefulness of any information, apparatus, product or process disclosed, or represents that its use would not infringe privately owned rights. 
Contract No. W-7405-eng-26

ISOTOPES DEVELOPMENT CENTER

\title{
RADIOISOTOPE PROGRAM (8000) PROGRESS REPORT FOR FEBRUARY 1973
}

\author{
A. F. Rupp
}

Work Sponsored by

AEC Division of Applied Technology

NOTICE

NOTCE This report contains information for internal use Thature and was prepared primart is subject to reat the or iginating installation. It is does not reprevision or currootinn and therefore the reninient in sent a final report. It is passed tu tho ran or further confidence and should not be ulustraction or iginating disclused withnut the approval of the origing

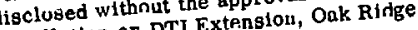

Installatlon or DTI Extens
MARCH 1973

NOTICE This docurterl contains information of a preliminary nature and was prepared primarily for internal use at the Oak Ridge National Laboratory. It is subject to revision or correction and therefore does not represent a tinal report.

\footnotetext{
OAK RIDGE NATIONAL IABORA'I'URY

Oak Ridge, Tennessee 37830

operated by

UNION CARBIDE CORPORATION .

for the

U.S. ATOMIC ENERGY COMMISSION
}

This report was prepared as an account of work sponsored by the United States Government. Nelther the United States nor the United States Atomic Energy Commission, nor any of their employees, nor any of their contractors, subcontractors, or their employees, makes any warranty, express or implied, or assumes any legal liability or responsibility for the accuracy, complotenass $\mathrm{nr}$ usefulness of any information, apparatus, product or process disclosed, or represents that its use would not infringe privately owned rights. 


\section{THIS PAGE}

WAS INTENTIONALLY

LEFT BLANK 
CONTENTS

RADIOISOTOPE PRODUCTION AND MATERIALS DEVELOPMENT . . . . . . . . 1

REACTOR-PRODUCED ISOTOPES . . . . . . . . . . . . 1

Phosphorus-33..................... 1

Potassium 43 ..................... 2

Platinum-195m .................... 2

Reactor Products Pilot Production............ 3

ACCELERATOR-PRODUCED ISOTOPES . . . . . . . . . . . 3

Bismuth-206 . . . . . . . . . . . . . . 3

Potassium-43 ..................... . . . 5

Cyclotron Products Pilot Production ............ 5

FISSION PRODUCTS . . . . . . . . . . . . . . 5

Krypton-85 Enrichment .. . . . . . . . . . . . . 5

Cesium-137 Pilot Production ... . . . . . . . . . . 6

Strontium-90 Pilot Production ............... 7

Promethium-147 Shipments and Current Orders . . . . . . 8

SOURCE DEVELOPMENT . . . . . . . . . . . . . . . . . . 8

Gadolinium-153 . . ................. 8

U1trahigh Specific Activity Cobalt-60........... 9

Iodine-125 .................... . . 9

Radioisotope Characterization, Quality

Control, and Standards ............... 10

RADIOISOTOPE SALES .................. 11

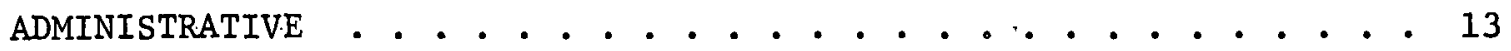

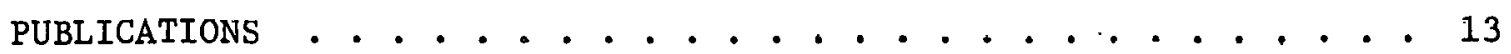

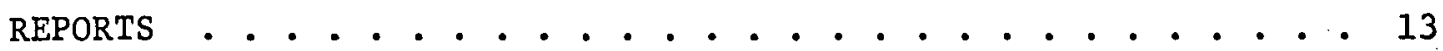


RADIOISOTOPE PROGRAM (8000) PROGRESS REPORT FOR FEBRUARY 1973

\author{
A. F. Rupp
}

\title{
RADIOISOTOPE PRODUCTION AND MATERIALS DEVELOPMENT
}

$$
\text { REACTOR-PRODUCED ISOTOPES - 08-01-01 }
$$

\section{Phosphorus -33 ( $J: K$. Poggenburg)}

\begin{abstract}
The purpose of this project is to develop methods of preparing hundred-millicurie quantities of carrierfree phosphorus-33 containing $\leq 5 \%$ phosphorus-32. The two methods for producing phosphorus-33 being evaluated are based on the irradiation of highly enriched targets of sulfur-33. (>92 at. \%) or chlorine-36 (approximately 63 at. \%) in a fast neutron flux. Phosphorus-33 (25.2 days; $0.248-\mathrm{MeV}$ $B_{\text {max }}$ ) has both a longer half-life and a lower energy beta than phosphoms-32. (14.3 days; 1.709-MeV $B_{\text {maxl }}$, which makes it advantageous for autoradiography, longer ecological and agricultural experiments than with phosphomis-32, synthesis of tagged complex organophosphoms compounds, and double labeling experiments.
\end{abstract}

Last month it was reported that the solution from a $1.06-\mathrm{g}$ (approximately $65 \%$ enriched) $\mathrm{K}^{36} \mathrm{Cl}$ target gave a. low. phosphorus -33 -yield upon. processing and showed upon analysis that it still contained what was thought. to be approximately. $900 \mathrm{mCl}$. phosphorus -33 . The solution. was converted to $\mathrm{H}^{36} \mathrm{Cl}$, and fresh. $\mathrm{Fe}(\mathrm{OH})_{3}$. was dissolved in the solution. Reprecipitation of $\mathrm{Fe}(\mathrm{OH})_{3}$ was again. carried out using KOH. The phosphorus-33 yield from this procedure was 110. $\mathrm{mCi}$. Since more phosphorus-33. was expected, the procedure was repeated using $\mathrm{NH}_{4} \mathrm{OH}$ to effect the precipitation. of. $\mathrm{Fe}(\mathrm{OH})_{3}$. Another $100 \mathrm{mCl}$. of phosphorus -33 was obtained. . At. this point the target solution was analyzed by counting Cerenkov and. liquid scintillation samples. While the liquid scintillation samples gave. significant count. rates, the Cerenkov count rate. was not consistent with what should be expected from the known fraction of phosphorus-32 in the phosphorus product. The Cerenkov count rate could, in fact, be accounted for by the expected chlorine-36 activity of the target. A beta-absorption sample was. prepared; the analysis showed only one beta-component, with a half-thickness consistent with sulfur-35. The quantitative beta analysis indicated. 1.3 $\mathrm{Ci}$ of sulfur-35 in the target. The sulfur-35 beta end-point energy. is. $16.7 \mathrm{keV}$, which does not excite a Cerenkov count. The liquid scintillation count was also consistent with $1.3 \mathrm{Ci}$ sulfur -35 .

The total amount of phosphorus-33 extracted. from this target was $500 \mathrm{mCi}$ at discharge. The procedure of converting the $\mathrm{K}^{36} \mathrm{Cl}$ target to $\mathrm{H}^{36} \mathrm{Cl}$ and 
adding $\mathrm{Fe}(\mathrm{OH})_{3}$ was adopted as a method to avoid. adding sulfate ion and to obviate the need for a $\mathrm{BaSO}_{4}$ precipitation. It now appears that the original procedure of adding $\mathrm{Fe}_{2}\left(\mathrm{SO}_{4}\right)_{3}$ and the subsequent $\mathrm{BaSO}_{4}$ precipitation is desirable to remove the sulfur -35 . which builds up. The recovery of the phosphorus-33 was also more reliable.. If greater effort to remove $\mathrm{SO}_{4}{ }^{2-}$ from the target is necessary (natural. sulfur also produces phosphorus-32), then excess. $\mathrm{Ba}(\mathrm{OH})_{2}$ can be added for the $\mathrm{BaSO}_{4}$ precipitation, followed by use of $\mathrm{a} \mathrm{H}^{+}$cation column and titration. with $\mathrm{KOH}$ to remove the barium. Also, use of alcohol to precipitate the $\mathrm{K}^{36} \mathrm{Cl}$ should remove additional traces of sulfate. We have been taking the salt directly to dryness since we were adding no foreign cations except the iron.

Since the target was left in the form of. $\mathrm{NH}_{4} \cdot{ }^{36} \mathrm{Cl}$ after the final $\mathrm{Fe}(\mathrm{OH})_{3}$ precipitation, it was recovered by adding phenolphthalein indicator and boiling down. to dryness with addition of $\mathrm{KOH}$ to indicator end point as the $\mathrm{NH}_{3}$. boiled off. The final $\mathrm{K}^{36} \mathrm{Cl}$ was. fired. at $450^{\circ} \mathrm{C}$, treated with decolorizing charcoal to remove the traces of degraded indicator, and recovered. as a pure white salt. It was then loaded into a target capsule for. reinsertion at the next reactor cycle. An $0.8-g_{2}{ }^{3}{ }^{3} \mathrm{SO}_{4}$ target was processed, but the phosphorus-32. content was $28 \%$. This target had only $6 \%$ phosphorus -32 at the last processing. A review of the procedures gives no reason. to suspect isotopic contamination. with sulfur-32. The target was recovered and will be reirradlated.

A target containing $1.13 \mathrm{~g}$ of $48 \%$ enriched. $\mathrm{K}^{36} \mathrm{Cl}$. was processed. It had been irradiated for six months and had decayed for one month. The phosphorus -32 content at processing was. $10 \%$, but. the $50 \mathrm{mCi}$ of phosphorus -33 obtained was blended with other material to fill orders for $200 \mathrm{mCi}$.

\section{Potassium-43 (J: K. Poggenburg)}

The objectives of this project. are to prepare potassium -43 by the ${ }^{43} \mathrm{Ca}(n, p){ }^{43} \mathrm{~K}$. reaction using isotopically enriched ${ }^{43} \mathrm{CaO}$ targets and to establish cooperative programs with medical institutions to evaluate it. Potassium-43 is potentially useful for metabolic and clinical. studies of blood flow, rejection of transplanted organs, and kidney function. The half-life of potassium-4.3 is $22.5 \mathrm{hr}$; ganma-rays are 0.373 and $0.617 \mathrm{MeV}$.

Three batches of potassium-43 were processed this month, and four shipments totaling $16 \mathrm{mCi}$ were made.

\section{Platinum-195m (J.K. Poggenburg)}

The objectives of this work are to develop. methods for preparing platinum isotopes. suitable. for. wholebody scanning in biological and medical experiments, to characterize the products, and to establish 
cooperative programs with medical. research groups interested in evaluating their usefulness.

Recent medical research has shown. that. some platinum compounds act as chemical therapeutic agents towards certain kinds of tumors. Platinum radioisotopes are needed for investigation of the therapeutic mechanism involved. Platinum-195m (4.0. d). has garma emissions of $99 \mathrm{keV} \mathrm{(11 \% )} \mathrm{and} 129 \mathrm{keV}(2.8 \%)$, that make it suitable for whole-body scanning.

A target of $95.95 \%$ enriched platinum-194 was irradiated $17.7 \mathrm{hr}$ in a thermal. flux of $2.3 \times 10^{15} \mathrm{n} / \mathrm{cm}^{2} \cdot \mathrm{sec}$; the platinum-195m specific activity was $1.06 \mathrm{mCi} / \mathrm{mg}$; and the cross section was calculated from these data to be 0.047 barn, which is. lower. than the reported value of 0.09 barn. A longer irradiation will be made to confirm the previous observation that for long irradiations the apparent cross section decreases., which would imply a large burnup cross section for the platinum-195m nuclide.

This highly. enriched target; low in platinum-196. (0..64\%) produced only one-third as much 20-hr platinum-19.7. as platinum-195m and would be. suitable for human use studies.

Reactor Products Pilot Production (R. W. Schaich) (Production and Inventory Accounts)

\begin{tabular}{lr}
\multicolumn{2}{c}{ Processed Units } \\
\hline Radioisotope & Amount \\
Calcium-47 & 23.9 \\
Zinc-69m & 1635.0 \\
Copper-67 & 29.0
\end{tabular}

\section{ACCELERATOR-PRODUCED ISOTOPES - 08-01-02}

Bismuth-206 (L. C. Brown)

I'he objectives of this program are to evaluate the pertinent production parameters and to provide bismuth-206 (6.24 d) for evaluation as a diagnostic radionuclide in medicine. Bismuth-208. Fus. ieen. used to delineate brain tumors in patients. with known brain tumors which are poox.ty visuulized by mor's common radionuclides. Even though very. favorable. tumorto-background activity ratio. has been obtained by earlier. workers, the lack of an appropriate scanning system suitable for the high-energy. emissions of this nuclide has retarded the evaluation of the isotope. 
Cooperative programs have been established with

Vanderbilt Medical School and the Medical Division of

ORAU for the evaluation of bismuth-206 as a diagnostic

radionuclide using high-energy photon scanning systems.

Test irradiations of natural isotopic abundance lead have been continued in an attempt to determine the optimal target thickness for bismuth-206 production via the ${ }^{207} \mathrm{~Pb}(\mathrm{p}, 2 \mathrm{n})^{206} \mathrm{Bi}$ reaction path. The results of these irradiations for the nat $\mathrm{Pb}(\mathrm{p}, x \mathrm{n})^{205} \mathrm{Bi}$ reaction are shown in $\mathrm{Fig}$. 1 for a target mounted at a $15^{\circ}$ angle to the beam. The yield of bismuth-205 was used to determine the $(p, 2 n)$ reaction path optimization since this isotope can be formed only by the ${ }^{206} \mathrm{~Pb}(\mathrm{p}, 2 \mathrm{n})^{205} \mathrm{Bi}$ reaction; whereas, bismuth-206 can be formed by both the ${ }^{206} \mathrm{~Pb}(\mathrm{p}, \mathrm{n})^{206} \mathrm{Bi}$ and the ${ }^{207} \mathrm{~Pb}(\mathrm{p}, 2 \mathrm{n})^{206} \mathrm{Bi}$ reactions. These values are based on a $28 \%$ photon intensity for the $703-\mathrm{keV}$ photon of bismuth-205. Assuming comparable cross sections for both the $206 \mathrm{~Pb}(\mathrm{p}, 2 \mathrm{n}){ }^{205} \mathrm{Bi}$ and ${ }^{207} \mathrm{~Pb}(\mathrm{p}, 2 \mathrm{n})^{206} \mathrm{Bi}$ reactions, one can estimate the bismuth-206 machine yield by multiplying the $x$ axis of Fig. 1 by a scale factor of approximately 9.6. This estimate neglects any contribution from the ${ }^{206} \mathrm{~Pb}(\mathrm{p}, \mathrm{n}){ }^{206} \mathrm{Bi}$ reaction, which should be minimal due to (1) the relatively high coulomb barrier for proton penetration at these high $Z$ 's and (2) the reduced lead-206 isotopic abundance in this enriched target (e.g., 2.16 atom \% vs 23.6 atom \% for natural isotopic abundance lead).

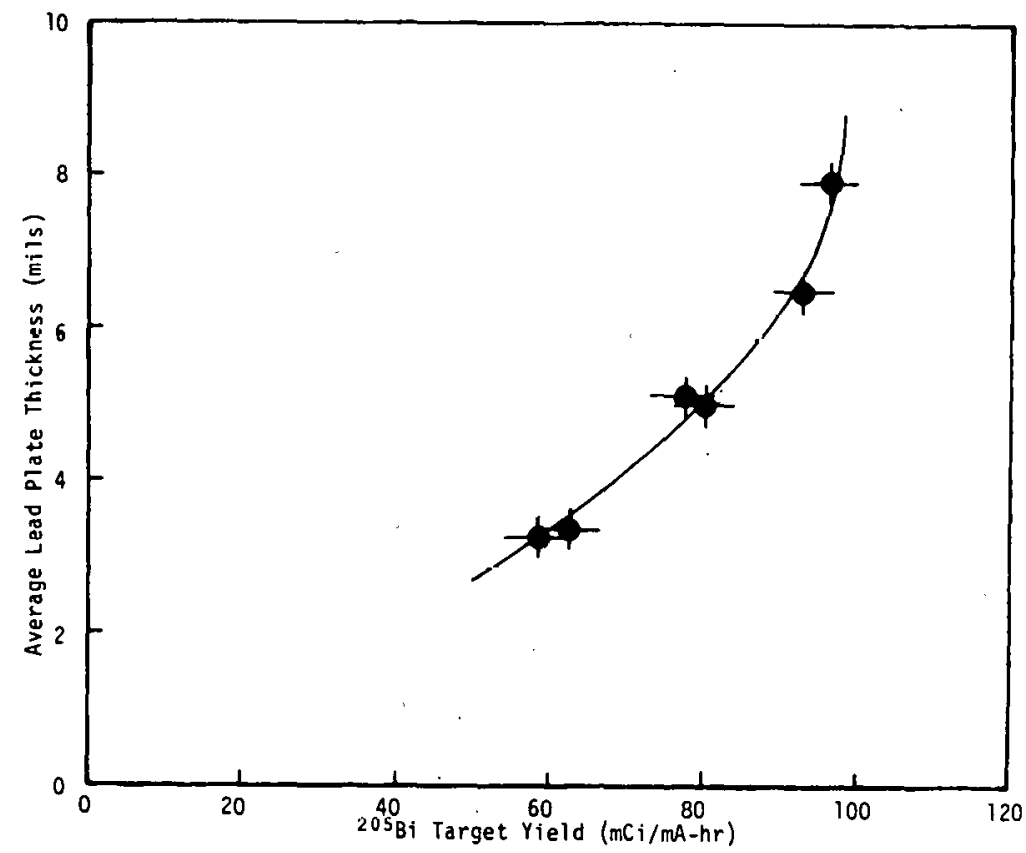

Fig. 1. Effect of Average Natural Lead Plate Thickness on Bismuth-205 Target Yields.

${ }^{1}$ A. F. Rupp, Radioisotope Program (8000) Progress Report for January 1973 , ORNL-TM-4106, Oak Ridge National Laboratory, p. 3. 
In order to demonstrate the purity of bismuth-206 possible with this target material, to provide some high-purity bismuth-206 product to the medical collaborators for evaluation, and to obtain enriched lead-207 target yield data points on Fig. 1, irradiations of the enriched target material will be performed at moderate power levels. A 0.005-in.-thick lead-207 target will be irradiated at a power level of approximately $4 \mathrm{~kW}$ (i.e., $180-\mu \mathrm{A}$ beam of $22-\mathrm{MeV}$ protons). A second irradiation of a $0.006-$ to 0.007-in.-thick target (near optimal thickness from the data in Fig. 1) will be performed.

Potassium-43 (J.K. Poggenburg and L. C. Brown)

The $\mathrm{CaO}$ target for the experiment to test production of potassium -43 by the ${ }^{44} \mathrm{Ca}(\gamma, \mathrm{p}){ }^{43} \mathrm{~K}$ reaction is ready, and it is hoped the irradiation will be accomplished at the beginning of next month.

Cyclotron Products Pilot Production (L. O. Love)

(Production and Inventory Accounts)

February 1973 ORNL 86-Inch Cyclotron runs for ORNL and non-ORNL programs are given in Table 1 .

Table 1. Cyclotron Irradiations and Runs for February 1973

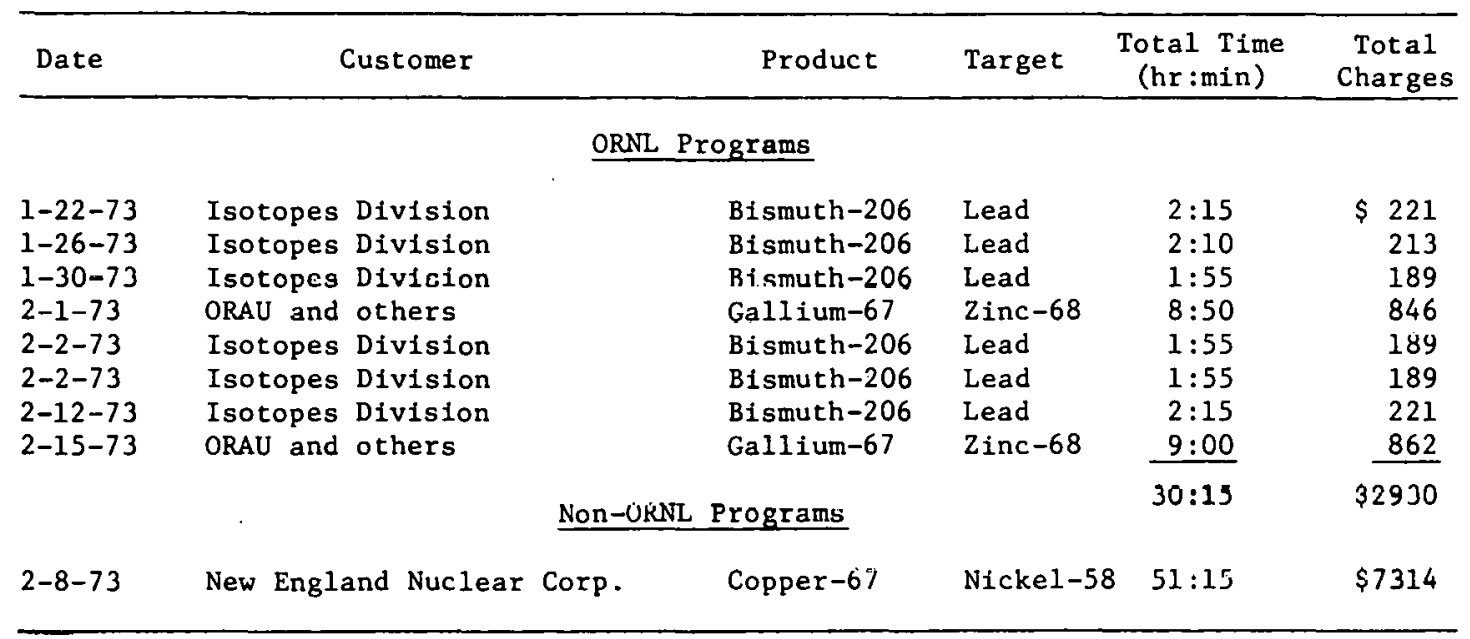

FISSION PRODUCTS - 08-01-03

\section{Krypton-85 Enrichment (R. A. Robinson)}

The leaking tube in the 8-tube section reported last month was found and, as suspected, leakage was the result of overheating due to a thick buildup of scale in the vicinity of the baffles. A more complete inspection of the tubes in this column and in another column that was removed from the cell indicates that many of the tubes in the center of each column bundle have experienced local overheating at points where they pass through the 
baffles and are severely distorted. Although there are no other leaks, these tubes are damaged to the extent that they should be replaced. Plans are in progress to dissolve the scale off these two bundles and the four remaining in the cells and to replace the damaged tubes.

Cesium-137 Pilot Production (R. W. Schaich)

(Production and Inventory Accounts)

\section{Process Status}

Attempts to process cesium oxalate by crystallizing in the concentrate crystallizer and jetting the slurry. to the filtration system were unsuccessful, probably due to redissolving of the crystals during jetting. The cesium-137 final processing. cell was decontaminated and the failed agitator was replaced. During the period that the cell was open, several large pieces of equipment were removed and discarded in preparation for a full decontamination after all cesium-137 has been processed. Since removal of these items would have been a necessary first step in the decontamination, the agitator replacement. resulted in little net loss in cesium-137 processing time. After the agitator was replaced, one cycle of cesium oxalate was run with an estimated yield of. 50,000 $\mathrm{Ci}$. Accumulation of filtrate and reconcentration for another oxalate cycle is in progress.

During the temporary shutdown of cesium-137 processing, several shipments of solid waste were made. Much of this was old equipment which had accumulated in the manipulator cells. over several years' time. All equipment small enough for airlock transfer except that needed to finish up strontium-90 and cesium-137 processing has been discarded.

A routine recheck on a ${ }^{137} \mathrm{CsCl}$ product showed an unusually high variation $(+10 \%)$ from the previous assay. After. some rechecking it was decided that severail analyses might be in error, and all available (i.e., unwelded) containers of product-grade material were resampled. Several batches were found to be higher in cesium-137. than had been indicated (none lower), and the ceslum-137 product inventory was adjusted accordingly. The current cesium-137 process status is as follows:

\section{$\underline{\text { Item }}$}

In-process material (estimated)

$137_{\mathrm{CsCl}}$ products

Sources in fabrication

Completed sources awaiting shipment

\section{Cesium-137 (Ci)}

110,000

479,100

190,600

\footnotetext{
$\mathrm{a}_{\text {The }}$ 180,000-Ci BNL order noted last month has been canceled.
} 
2. Operational Summary

\begin{tabular}{|c|c|c|c|c|c|c|}
\hline \multirow[b]{2}{*}{ Item } & \multicolumn{2}{|c|}{ Feb. 1973} & \multicolumn{2}{|c|}{ CY 1973} & \multicolumn{2}{|c|}{ FY 1973} \\
\hline & No. & $\mathrm{C}_{1}$ & No: & $\mathrm{C}_{1}$ & No.. & $\mathrm{C}_{1}$ \\
\hline HAPO shipments received. & 0. & 0 & 0 & 0 & 0 & 0 \\
\hline Product batches prepared & 0 & 0 & 8 & 150,000 & 38 & 457,000 \\
\hline Sources & & & & & & \\
\hline Fabricatéd & 0 & 0 & 8 & 22,750 & 34 & 48,450 \\
\hline Shipped & 6 & 11,700 & 7 & 14,700 & 33 & 45,400 \\
\hline Special form cans & & & & & & \\
\hline $\begin{array}{l}\text { Fabricated } \\
\text { Shipped }\end{array}$ & $\begin{array}{r}41 \\
5\end{array}$ & $\begin{array}{r}5,200 \\
700\end{array}$ & $\begin{array}{r}41 \\
6\end{array}$ & $\begin{array}{r}5,200 \\
950\end{array}$ & $\begin{array}{l}51 \\
10\end{array}$ & $\begin{array}{l}5,700 \\
2,450\end{array}$ \\
\hline
\end{tabular}

3. Current Orders

Current orders for cesium-137 as sources or bulk power are listed below:

\section{Customer}

J. L. Shepherd \& Associates, Inc. Radiochemical Centre
Amount Estimated

(C1) Shipping Date

21,754. March \& May 1973

1,500 May 1973

An order is on hand from Aţomic. Energy of Canada, Limited, for $\sim 63 \mathrm{kCl}$ of cestum-137 as $\mathrm{CsCl}$ powder... The powder has been canned and stored and is awafting release by customer.

\section{Source Fabrication}

Six cesium-13.7 sources totaling. 11,754. Ci were fabricated for J. L. Shepherd and Associates, Inc.. Four sources totaling $200 \mathrm{CI}$ were fabricated for General Radiolsotope. One 500-C1 source was fabricated for 3-M Company.

Strontium-90 Pilot Production. (R.. W.. Sahaich)

(Production and Inventory Accounts)

1. Process Status

No strontium-90 processing was done this month. As part of the preparation for manipulator. cell decontamination., several containers of assorted strontium-90 materials were removed. from in-cell storage to carrier storage. These materials included ${ }^{90} \mathrm{SrSiO}_{3}$, low-grade ${ }^{30} \mathrm{Sr}_{2} \mathrm{I}^{\prime} 1 \mathrm{U}_{4}$, and solld waste high in strontium-90. Weldable containers are. being prepared for storage of the present inventory, of source-grade. ${ }^{90} \mathrm{Sr}_{2} \mathrm{~T}_{10} \mathrm{O}_{4}$ so that it can also be removed from in-cell storage. The current strontium-90 process status is as follows. 
Item

In-process material Strontium-90 products Sources in fabrication.

Returned SNAP sources

Completed sources awaiting shipment
Strontium-90 (Ci)

805,900

426,200

446,600

221,000

\section{Operational Summary}

There were no operational entries: for February 1973, CY 1973 ; or FY:1973 except shipment of orie 10-Ci: special form can.

\section{Current Orders}

Current orders for strontium-90 as sources or bulk powder are listed below:

\begin{tabular}{lrrr}
\multicolumn{1}{c}{$\begin{array}{rr}\text { Customer } \\
\text { U. S. Navy }\end{array}$} & $\begin{array}{c}\text { Amount } \\
\left(C_{i}\right)\end{array}$ & $\begin{array}{c}\text { Estimated } \\
\text { Shipping Date }\end{array}$ \\
Radiochemical Centre & 221,000 & FY 1973 \\
& 500 & May 1973
\end{tabular}

Short-Lived Fission Products Pilot Production (R. W. Schaich)

(Production and Inventory Accounts)

Isotope Number of Batches Amount (Ci)

Xenon-133
Yttrium-91
Zircontum/N1obium-95
1

1

1

$\begin{array}{r}350.0 \\ 3.1 \\ 23.2 \\ \hline\end{array}$

376.3

Promethium-147 Shipments and Current Orders

Donald W. Douglas has placed an order for $200,000 \mathrm{Ci}$ of promethium-147. Shipments of 50,000 Ci will. be made in May, July, October, and December 1973. Minnesota Mining \& Manufacturing. Company will receive a shipment of 5,001 $\mathrm{Ci}$ promethium-147 in late February.

SOURCE DEVELOPMENT - 08-01-04

Gadolinium-153 (F. N. Case)

Nine separation runs for purification of gadolinium-153 were made using a high-pressure ion-exchange. column.. . Each. run consisted of approximately $100 \mathrm{mg}$ of gadolinium-152 target. that had been irradiated in the HFIR. This 100-mg quantity is the maximum quantity that can be loaded on the 
ion-exchange column for. optimum separation. of terbium-160 and europium-155 from the irradiated gadolinium-152. targe.t.. The yield of product quality gadolinium-153 (<10 ppm total radiochemical impurity) from the nine runs was $7 \mathrm{Ci}$.

Calculations to determine the optimum irradiation time in the HFIR at a neutron flux of $2 \times 10^{15} \mathrm{n} / \mathrm{cm}^{2} \cdot \mathrm{sec}$ indicate that maximum production of gadolinium-153 is achieved in 2.5 to. 3 days. The yield from the targets irradiated. for. 1. day and. 2. days produced 13. and $16 \mathrm{mCi} / \mathrm{mg}$ of target, respectively. Additional targets have been. prepared for irradiation to give a projected yield of 15 to $20 \mathrm{Ci}$ of gadolinium-153.

Six sources were prepared from the purified product. These sources, used in process control, have been placed in operation in routine production for control of trace elements and coating thickness.

Sources are being prepared for several different medical groups who plan to carry. out brain and organ transmission. scanning research using gadolinium-153 as an external. source of radiation, bone density measurements to determine changes in bone density of. the astronauts involved in Skylab experiments, and determination of. lead. in children by use of transmission scanning and x-ray fluorescence techniques. for thyroid. scan. All of these proposed medical uses involve the application of radiation externally with the total radiation. dose. to. the patient. being from 100 to. 1000 times less than when scans are made by organ uptake of the radionuclide.

A large (20-Ci) source will be prepared for use in the development of single.wire position-sensitive detectors under development in the ORNL Instrumentation and Controls Division.

A. separation run for recovery of semipurified gadolinium-152 from the HFIR control plates will be made during March.

Ultrahigh Specific Activity Cobalt-60 (F. N. Case)

$\mathrm{Plans}$ are being made for the preparation of $1000 \mathrm{C} 1$ of cobalt-60 having a specific activity of greater. than 1000 . Co./g for use by an AEC facility in radiographic inspection procedures.. . Feed for this preparation is available from high burnup cobalt-59. prepared approximately three years ago. Hickel will be removed by ion exchange, and the cobalt-60 will be electrolytically reduced to elemental. form. for pressing into a small pellet.. The utility of ultrahigh specific activity cobalt in radiographic procedures has been demonstrated as necessary for high-resolution imaging in $A E C$ production operations.

Iodine-125 (F. N. Case)

A method for preparing very small sources of lodine-125 that have minimum self-absorption was developed. to fill. a. need: by Brookhaven National Laboratory. that could not be met commercially.. Iodine-125 (half-life 60 days) decays by electron capture through the $0.035-\mathrm{MeV}$ level of 
tellurium-125. The $0.035-\mathrm{MeV}$ gamma is highly converted so that most of the radiation is tellurium $x$ rays. within the energy range of 27.2 to $31.7 \mathrm{keV}$. To prepare a high output source, the fabrication methods require much attention to problems of.self-absorption. In the particular application planned, the radiation source is required to be a 1 -mm-diam sphere emitting radiation $180^{\circ}$ from the surface of the sphere.

Using iodine-131 tracer, a method was developed in which iodine can be reduced to elemental iodine by using sodium iodide as starting feed and extracting the free lodine into a small volume of carbon tetrachloride. A 1-mm-diam copper bead, when exposed to the $\mathrm{CCl}_{4}$ solution of iodine, will adsorb the iodine present. The copper iodide formed appears to be stable and.will provide a useful source of tellurium $x$ rays. Copper samples in various configurations were reacted with 1-ml portions of $\mathrm{CCl}_{4}$ solution containing $5 \mathrm{\mu g}$ of lodine. Yields of absorbed iodine are shown in Table 2 .

Table 2 . Reaction of Iodine with Copper

\begin{tabular}{cc}
\hline Form of Copper & $\%$ Reacting \\
\hline 4.4-mg Cu foil. & 91.5 \\
$1.0-\times 1.0-\times 0.02-\mathrm{mm}$ foil & 88.0 \\
$5.0-\mathrm{mg}$ solid & 56.0 \\
$5.3-\mathrm{mg} \mathrm{Cu}$ foil, rolled into ball & 94.6 \\
$5.0-\mathrm{mg} C u$ foil, rolled into ball & 68.4 \\
\hline
\end{tabular}

Radioisotope Characterization, Quality

Control, and Standards (S. A. Reynolds)

\section{Radioisotope Characterization}

An inquiry on absorption of beta radiation from nicke1-63 was answered by reference to a paper and an old report of ours, ORNL-788 (1950). The half-thickness in aluminum is about. $0.6 \mathrm{mg} / \mathrm{cm}^{2}$. Information from the "Radioactive Atoms" table (Nuc.l. Data) sufficed for most of the response to an inquiry from the College of American Pathologists for decay-scheme parameters for radiopharmaceuticals. Another inquiry about the half-life of barium-133 led to a review of probable impurities leading to others' low values. Secondary-product cesium-134 seems the most likely candidate.

\section{Radioisotope Special Analysis and Quality Control .}

Our change in basis of assay of. gallium-67 (last month) and corresponding change in price was announced. in. a. let.er. to users and standards groups. The College of American Pathologists asked and received permission to use 
our statistical analysis of their intercomparison on chromium-51 assay, which showed a standard. deviation. of. 12-13\%. An inquiry on decomposition of water vapor prompted a literature survey. of radiolytic, photolytic, and other methods, but none were found that. were very efficient. Other inquiries were concerned with analysis of iridium, standards for alpha measurements, and methods for measurements of activities in gaseous and liquid wastes.

\section{RADIOISOTOPE SALES \\ (J. E: Ratledge)}

An inquiry was received from the. British Embassy, Washington, D. C., regarding availability of strontium-90 as sources. in quantities greater than $100 \mathrm{kCi}$. A notice of cancellation. was. received from Brookhaven National Laboratory of their order for cesium-137. . Two orders were received from Minnesota Mining and Manufacturing Company for $5676 \mathrm{Ci}$.of promethium-147 as bulk powder.

An order was received from Radiochemical. Centre for $1 \mathrm{Ci}$ each of $6 \%$ and 93\% abundance (enriched) radiosamarium-151. An order was received from International Chemical and. Nuclear. Corporation for $700 \mathrm{mCi}$ of phosphorus-33 to be shipped at the rate of $100 \mathrm{mCi}$ every 50 days. An order was received from New England Nuclear Corporation. for. $300 \mathrm{mCl}$ of phosphorus-33 to be shipped at the rate of $100 \mathrm{mCi}$ every month.

Shipments made during the month that may be of interest are listed below:

Customer

\section{Large Quantities}

New England. Nuclear Corporation

KMS Fusion, Inc.

U. S : Radium Corporation

Canrad Prccioion Industries, Inc.

Schwarz / Mann

Minnesota Mining \& Manufacturing Company

Minnesota Mining \& Manufacturing. Company

Industrial Nucleonics Corporation

Withdrawn Items

Cleveland Metropolitan General Hospital

Mayo Clinic.

University of Chicago

McClellan Air Force Base
Isotope

Amount

$\begin{array}{lr}\text { Tritium } & 8,000 \mathrm{Ci} \\ \text { Tritium } & 2,000 \mathrm{Ci} \\ \text { Tritium } & 10,000 \mathrm{Ci} \\ \text { Tritium } & 1,000 \mathrm{Ci} \\ \text { Tritium } & 1,500 \mathrm{Ci} \\ \text { Promethium-147 } & 675 \mathrm{Ci} \\ \text { Cesium-137 } & 500 \mathrm{Ci} \\ \text { Krypton-85, enriched } & 200 \mathrm{Ci}\end{array}$

Iodine-131, FP

$400 \mathrm{mCi}$

Copper -67

Copper-67

Copper -67

$10 \mathrm{mCi}$

NiO $\mathrm{mCI}$

$10 \mathrm{mCi}$ 
Customer

Isotope

Amount

Items Used in Cooperative Programs

Vanderbilt University

University of Southern California

Oak Ridge Associated Universities
Bismuth-206

Pilatinum-195m

Gallium-67 $\sim 5 \mathrm{mCi}$

$\sim 30 \mathrm{mCi}$

$\sim 400 \mathrm{mCi}$

Unusual Items

Gamma Industries

Cesium-137

$\sim 5 \mathrm{Ci}$

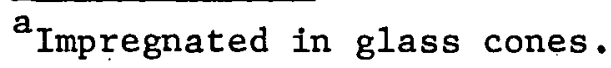

A summary of radioisotopes shipped during January 1973 is given in Table 3 . Table 3. Summary of Radioisotopes Shipped During January 1973

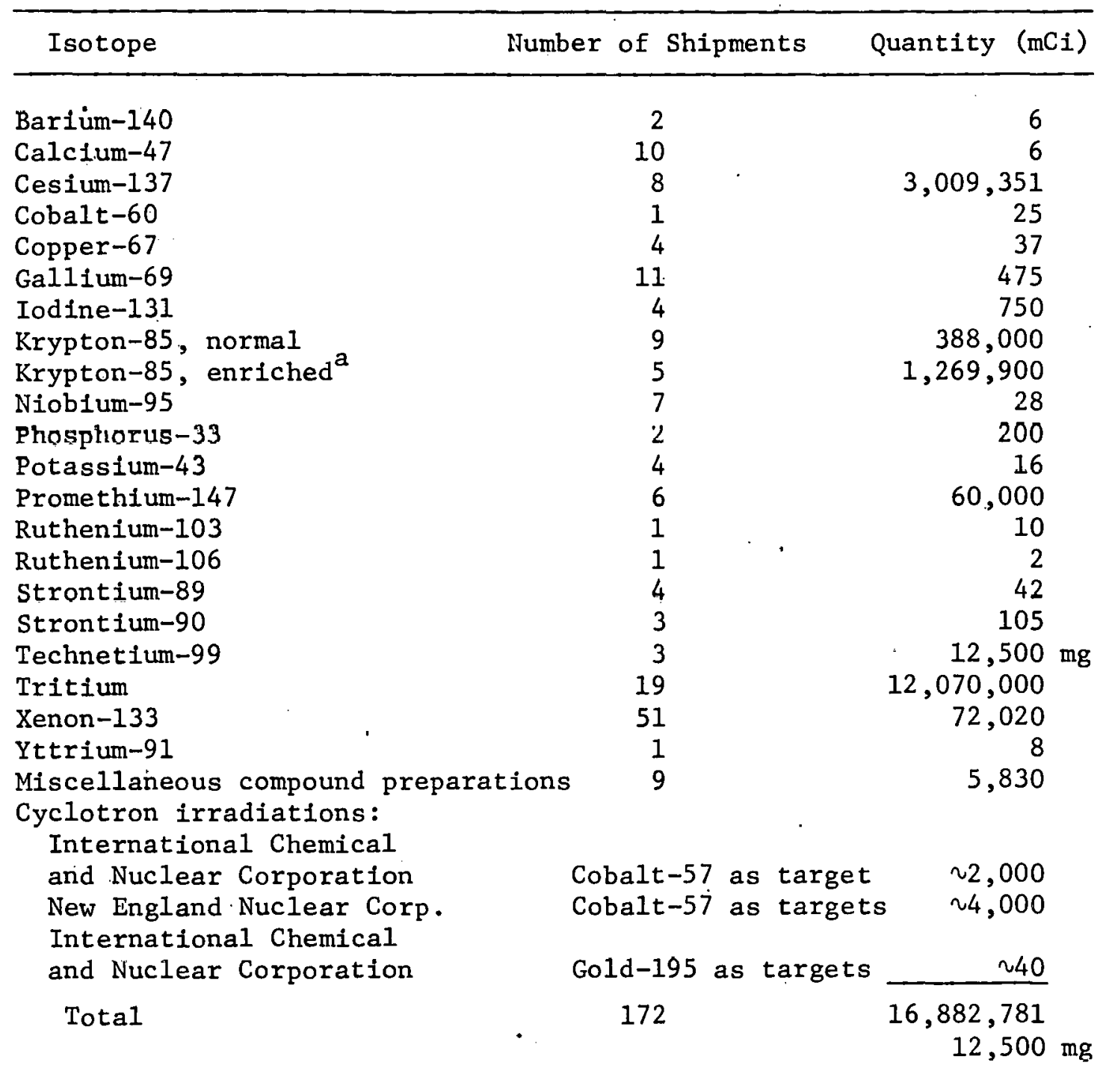

ancludes $973.8 \mathrm{Ci}$ of enriched krypton-85 billed to Measurex Corporation but not shipped. 
The radioisotopes sales proceeds and shipments for the first seven months of FY 1972 and FY 1973 are given in Table 4.

Table 4. Radioisotope Sales and Shipments

\begin{tabular}{lrr}
\hline \multicolumn{1}{c}{ Item } & $\begin{array}{r}7-1-71 \text { thru } \\
1-31-72\end{array}$ & $\begin{array}{c}7-1-72 \text { thru } \\
1-31-73\end{array}$ \\
\hline & & \\
Inventory items & $\$ 259,622$ & $\$ 288,519$ \\
Major products & 37,957 & 33,281 \\
ORNL 86-Inch Cyclotron & 87,361 & 74,710 \\
Radioisotope services & 162,035 & 100,538 \\
Miscellaneous processed materials & 36,892 & 30,746 \\
Packing and shipping & 42,355 & 39,407 \\
\multicolumn{1}{c}{ Total } & $\$ 626,222$ & $\$ 567,201$ \\
Number of shipments & 1,449 & 1,214 \\
\hline
\end{tabular}

\section{ADMINISTRATIVE}

The only travel during. February was a trip by.. J. H. Gillette and E. Lamb to DAT, Washington, D. C., to discuss close-out costs for the 08 Program.

\section{PUBLICATIONS}

\section{REPORTS}

J. H. Gillette, Isotope Program. (5000). Progress Report for Quarter Ending December 31, 1972, ORNL-TM-4117, Oak Ridge National Laboratory.

E. Lamb; Isotopic Power. Fuels. Monthly Status Report for January 1973, ORINL-TM-4130, Oak Ridgc National Lahnratory.

A. F. Rupp, Radioisotope Program (8000) Progress Report for January 1973 , ORNL-TM-4106, Oak Ridge National Laboratory.

JOURNAL-S

J. C. Manthuruthil, D. C. Camp, A. V. Ramayya, J. H. Hamilton; J. J. Pinajian, and J. W. Doornebos: "Excited States in $206 \mathrm{~Pb}$ from the Decay of $20{ }^{\mathrm{Bi}}$," Phys: Rev. 6(5), 1870-89 (November 1972).

J. Lange, J. 1!: Hamilton, P. E. Little, D. L. Hattox, D. C. Morton, I. C. Whitlock, and J. J. Pinajian, "E2-M1 Admixtures of Transitions in $68 \mathrm{Zn}, "$ Phys. Rev. $\underline{7}(1), 177-79$ (January 1973).

A. C. Rester , B. van looijen, P. Spilling, J. Knnijn, and J. J. Pinailan, $18{ }^{4} \mathrm{Sr}\left(x, x^{\prime}\right)$ and ${ }^{84} \mathrm{Sr}\left(x_{1}, x^{-} \gamma\right)$ Measurements with 13-MeV Protuns, $12=\mathrm{MeV}$ Deutrons, and 18-MeV a Particles," Phys. Rev. 7(1), 210-16 (January 1973). 
THIS PAGE

\section{WAS INTENTIONALLY LEFT BLANK}


INTERNAL DISTRIBUTION

$\begin{aligned} & \text { 1. } \text { M. A. Baker } \\ & \text { 2. } \text { P. S. Baker } \\ & \text { 3. } \text { E. E. Beauchamp } \\ & \text { 4. } \text { G. E. Boyd } \\ & \text { 5-7. T. A. Butler } \\ & \text { 8. F. N. Case } \\ & \text { 9. } \\ & \text { 10. R. Casto } \\ & \text { 11. F. A. Cox } \\ & \text { 12. } \text {. } \text {. C. Culler } \\ & \text { 13. J. H. Gillette } \\ & \text { 14. H. R. Gwinn } \\ & \text { 15. R. F. Hibbs } \\ & \text { 16. K. E. Jamison } \\ & \text { 17. Lynda Kern. } \\ & \text { 18. E. H. Kobisk } \\ & \text { 19. E. Lamb. } \\ & \text { 20. L. O. Love. } \\ & \text { 21. W. S. Lyon } \\ & \text { 22. R. E. McHenry. }\end{aligned}$

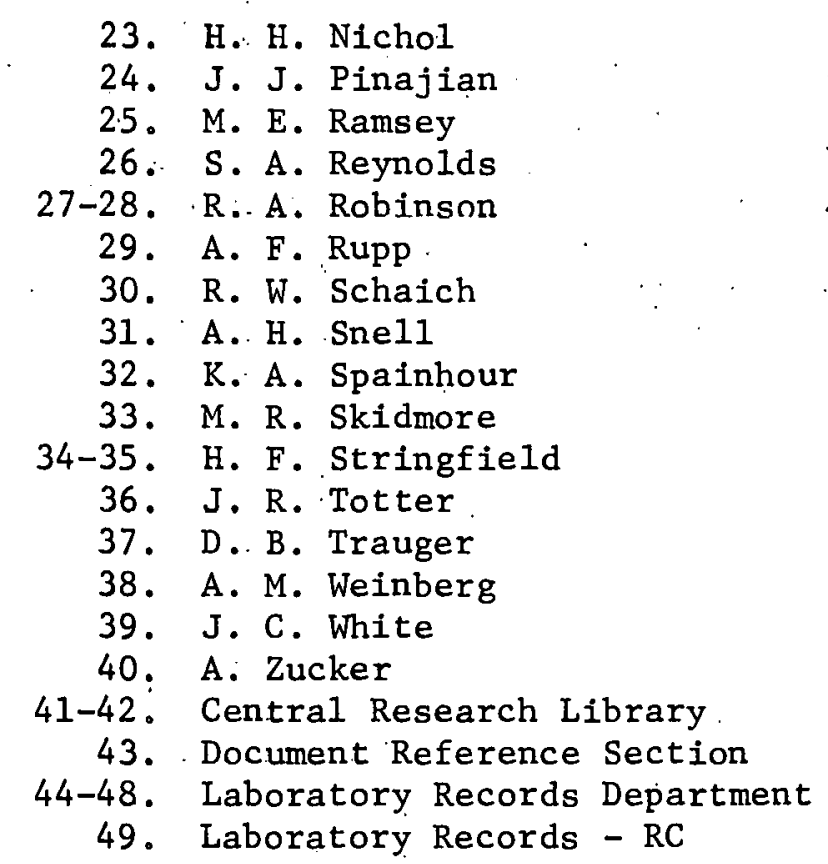

\section{EXTERNAL DISTRIBUTION}

50. G. A. Andrews, ORAU, Medical. Division,, Oak. Ridge, Tennessee

51. H. L. Atkins, Brookhaven National. Laboratory, Upton, New York

52. D. S: Ballantine, AEC, Washington, D. C.

53-56. R. F. Barker, AEC, Washington, D.. C..

57. N. F. Barr, AEC, Washington, D.. C .

58. G. L. Borsheim, ARHCO, Richland, Washington

59. C. R. Buchanan, AEC, Washington., D. C..

60. R. L. Butenhoff, AEC, Washington, D. C.

61. T. D. Chikalla, PNL, Richland, Washington

62. D. F. Cope, AEC Site Representative, ORNL

63. J. C. Dempsey, AEC, Washington., D.. C .

64. B. J. Dropesky, LASI, Los Alamos; Now Mexico

65. E: E. Fowler, AEC, Washington, D. C.

66. J. D. Goldstein, AEC, Washington, D. C :

67. A. Gottschalk, Argonne Cancer. Research Hospital, Chicago, Illinois

68. F. D. Haines, AEC, Wash1ngton, D. C.

69. W: D. Holloman, AEC, Washington, D. C.

70-72. J. H. Jarrett, PNL, Richland, Washington

73. D. K. Jones, AEC, Richland, Washlugton

74. J. Lawrence, Lawrence Berkeley Laboratory, Berkeley, California

75. J. E. Machurek, AEC, Washingtun, D. C.

76. J. N. Maddox, AEC, Washington, D. C.

77. J. C. Malaro, AEC, Washington, D. C.

78. B. Manowitz, Brookhaven National Laboratory, Upton, New York.

79. L. A. Miller, AEC, Washington, D. C.

80. W. E. Mott, AEC, Washington, D.: C .

81. H. A. O'Brien, LASL, Los Alamos, New Mexico 
82. G. J. Rotariu, AEC, Washingtion, D. C.

83. W. D. Sandberg, AEC, Aiken, South Carolina

84. R. W. Shivers, AEC, Washington, D. C.

85. F. J. Skozen (Krizek), Argonne Cancer Research Hospital, Chicago

86. Robert E. Smith, Atlantic Richfield Hanford Company, Richland, WA

87. L. G. Stang, Jr., BNL, New York

88-93. D. H. Turno, SRL, Alken, South Carolina

94. A. R. Van Dyken, AEC, Washington, D. C.

95. Research and Technical Support. Division, ORO

96-97. Technical Information Center 